\title{
Determination of Flower, Pod and Seed Characteristics Related to Yield Components in Forage Pea Genotypes
}

\author{
Süleyman Avcı ${ }^{1, a, *}$, Onur İleri ${ }^{1, b}$, Ali Koç ${ }^{1, \mathrm{c}}$ \\ ${ }^{I}$ Department of Field Crops, Faculty of Agriculture, Eskişehir Osmangazi University, 26160 Eskişehir, Turkey \\ *Corresponding author

A R T I C L E I N F O A B S T R A C T \\ Research Article \\ In this study which was carried out during the 2015 summer season in Eskişehir, the flower, pod \\ and seed characters attributed to yield components were investigated in 12 forage pea genotypes. \\ They showed significant differences in terms of agronomic and morphological (flower, pod, and \\ seed) traits. The highest fresh hay yield with $2171 \mathrm{~kg} / \mathrm{da}$ and plant height with $106.6 \mathrm{~cm}$ were \\ Received : $16 / 05 / 2020$ \\ Accepted : 09/07/2020 \\ obtained from Populasyon-1. Crackerjack had lower values in some flower traits such as, whereas \\ the higher values of pod and seed traits were obtained from cv. Rose. In addition, Population-1 \\ included in the higher value group for standard petal width, keel petal length, calyx tube and teeth \\ lengths, and flower length. Although cluster analysis did not reflect agronomic traits, the clustering \\ resulted in four groups. The first group consisted of Özkaynak 1, 2, and 3 and Taşkent, Töre, and \\ Population-2, which were the standard petal colour violet, light, and dark violet. Population-1 had \\ Keywords: \\ Pea \\ Petal \\ Trait relation \\ Fresh hay yield \\ Correlation \\ both violet and white standard petal; however, it was included in the second group together with \\ white-flowered Ulubatlı and Ürünlü according to cluster analysis. While Rose and Gölyazı were in \\ the third group, Crackerjack was in the fourth group alone. There was a highly significant positive \\ correlation between fresh hay yield and both standard petal width and length and flower length. \\ Consequently, a hopeful result for summer growing in Eskişehir condition was obtained from \\ Population-1. It was suggested that some flower characters can be used for pre-selection of yield- \\ related traits in the evaluation of genetic diversity of pea germplasm through morphological trait.
}

savci@ogu.edu.tr alikoc@ogu.edu.tr https://orcid.org/0000-0002-4653-5567 https://orcid.org/0000-0001-5072-462X b@oileri@ogu.edu.tr

https://orcid.org/0000-0003-0728-4731

\section{Introduction}

Pea (Pisum sativum ssp. arvense L.) is one of the four most important legume products worldwide following soybean, peanuts and beans. It has been used as both food and livestock feed, especially in temperate regions (Muehlbauer et al., 1997). The varieties of pea can be classified as garden pea (green peas as vegetables), field pea (dry pea for feed and food), and forage pea grown primarily for livestock feed. Forage pea is a high-yield, short-term product with high protein content (Fraser et al., 2001), while it is also used for green manuring (Oelke et al., 1991).

$P$. sativum has a wide range of genetic variations and its wild species range from Iran and Turkmenistan to Asia Minor, North Africa and southern Europe (Maxted and Ambrose, 2000; Maxted et al., 2010). Turkey has a rich genetic diversity in terms of 4 lineages (Linage A, B, C, and D) determined in the phylogeographic study using 3 different markers in $P$. fulvum, $P$. abyssinicum, and $P$. sativum subsp. elatius taxa (Kosterin et al. 2010). It is of great importance to evaluate this genetic diversity in breeding programs.

Genetic variability is considered an important factor, which is the basic prerequisite of the crop breeding program to achieve high-yielding generations (Tiwari ve Lavanya, 2012). Evaluation of genetic variability with morphological, physiological, genetic, and cytogenetic techniques is important in determining the phylogenetic relationship of genotypes in the existing germplasm. However, some important consistent phenotypic markers, which do not change depending on environmental factors, related to yield and quality factors facilitate the preselection of genotypes in breeding programs.

Morphological characterization is the first step in the identification and classification of germplasm (Smith \& Smith, 1989). In the studies conducted by, Tan et al. (2012), Tan et al. (2013) and Demirkol and Y1lmaz (2019) compared forage pea genotypes collected from different locations with commercial varieties to identify promising 
local ecotypes, there were important differences between the genotypes in terms of the agro-morphological characters. Ali et al. (2007), Nisar et al. (2008), Gatti et al. (2011), Nisar et al. (2011) and Umar et al. (2014) found that the genetic diversity in peas and their relationship with the yield components were mostly based on agromorphological characters.

In this study, more specific flower, pod and seed characteristics of forage pea genotypes and their association with yield components were investigated.

\section{Materials and methods}

Ten forage pea genotypes and three lots of Özkaynak were used as material (Table 1). The experiment was conducted at Eskişehir condition during summer season of 2015 year.

Field experiment was arranged in a randomized complete block design with four replications. Seeds of forage pea genotypes were sown in soil with adequate soil water to encourage germination on March 12, 2015, in an amount of $15 \mathrm{~kg} / \mathrm{da}$ with a spacing between rows of $30 \mathrm{~cm}$. Diammonium phosphate (18-46-0) fertilizer $(17 \mathrm{~kg} / \mathrm{da})$ was applied with sowing and irrigation was not performed during the development period.

The measurements on standard petal, keel petal, wing petal, calyx and flower were carried out ten randomly selected plants to reveal their flower characteristics when they were fully flowering. Also the same amount of sample was evaluated to determine of pod and seed characters after seed harvest. The plants were harvested for fresh hay yield on June 25, 2015, when the lower pods began to swell.

The data were analyzed by using SPSS 16 package program and indicated as mean \pm standard error. Forage pea genotypes were classified according to flowers, pod and seed characters by using Principle Component and Cluster Analysis in Jump software. In addition, correlation analysis was performed to reveal the association between the agronomic and specific morphologic traits belong to flower, pod and seed.

Table 1. Breeding institution or sources and flower colors of forage pea genotypes

\begin{tabular}{l|lllll}
\hline \multirow{2}{*}{ No } & Forage Pea & \multirow{2}{*}{ Breeding institution or sources } & \multicolumn{3}{c}{ Colours of flower parts } \\
\cline { 4 - 6 } & Genotypes & & Standard petal & Wing petal & Keel petal \\
\hline 1 & Crackerjack & Alfa Tohum & White & White & White \\
2 & Ürünlü & Uludağ University, FA & White & White & White \\
3 & Özkaynak-1 & Selçuk University, FA & Violet & Dried rose & White \\
4 & Ulubatlı & Uludağ University, FA & White & White & White \\
5 & Population-1 & Russian & White or Violet & White or Dried rose & White \\
6 & Rose & Alfa Tohum & Violet & Dried rose & White \\
7 & Töre & Namık Kemal University, FA & Dark violet & Dried rose & Violet \\
8 & Özkaynak-2 & Selçuk University, FA & Violet & Dried rose & White \\
9 & Taşkent & Selçuk University, FA & Light violet & Dark violet & White \\
10 & Population-2 & North East Anatolia & Violet & Dried rose & Light violet \\
11 & Özkaynak-3 & Selçuk University, FA & Violet & Dried rose & White \\
12 & Gölyazı & Uludağ University, FA & White & White & White \\
\hline
\end{tabular}

FA: Faculty of Agriculture

\section{Results and Discussion}

Agronomic traits of forage pea genotypes indicated significant differences (Figure 1 and Figure 2). Plant height varied in the range of $70.6 \mathrm{~cm}$ to $106.6 \mathrm{~cm}$ in Crackerjack and Population-1, respectively (Figure 2). However, Population-1 had similar values with genotypes with Crackerjack, Rose, and Ürünlü. Fresh hay yields ranged from $1683 \mathrm{~kg} / \mathrm{da}$ to $2171 \mathrm{~kg} / \mathrm{da}$ in Rose and Population-1, respectively (Figure 3). In addition, there were no significant differences between genotypes other than Population-1 regarding fresh hay yield.

Flower parts of forage pea genotypes had different colors except for the white flowering genotypes (Table 1, Figure 1). Population-1 indicated both white and violet flower parts. All petal parts were white in Crackerjack, Ürünlü, Ulubatlı and Gölyazı. Standard petal of Özkaynak 1, 2 and 3, Rose and Population-2 were violet whereas Töre and Taşkent were dark or light violet, respectively. Their wing petal was dried rose except for Taşkent, which had dark violet. These genotypes had white keel petal except for Töre and Population-2, which had violet and light violet, respectively.
The studied genotypes showed a large variation for flower, pod and seed traits (Table 2). The standard petal length and width, wing petal length and flower length of Crackerjack was remarkably lower than other genotypes. Population-1 included in higher value group for standard petal width, keel petal length, calyx tube and teeth lengths, and flower length, while it had the lowest number of seeds in a pod. Rose genotype had high values in terms of wing petal length and width, calyx teeth length, pod length and width, seed length, and width.

Forage pea genotypes were classified under four groups according to the mean values of flower, fruit, and seed characteristics by using the principal component and cluster analysis (Figure 4). The change in flower colour among genotypes was partially reflected by this grouping. Except for Population-1 and Rose, colourful flowering genotypes such as Özkaynak 1,2 and 3, Taşkent, Töre and Population-2 had grouped under the first cluster. Although Population-1 had both white and colourful flowers, it placed in the second group with white flowers together with Ulubatlı and Ürünlü. Gölyazı with white flower and Rose with colourful flowers were in third group, while Crackerjack was in the fourth group alone. 

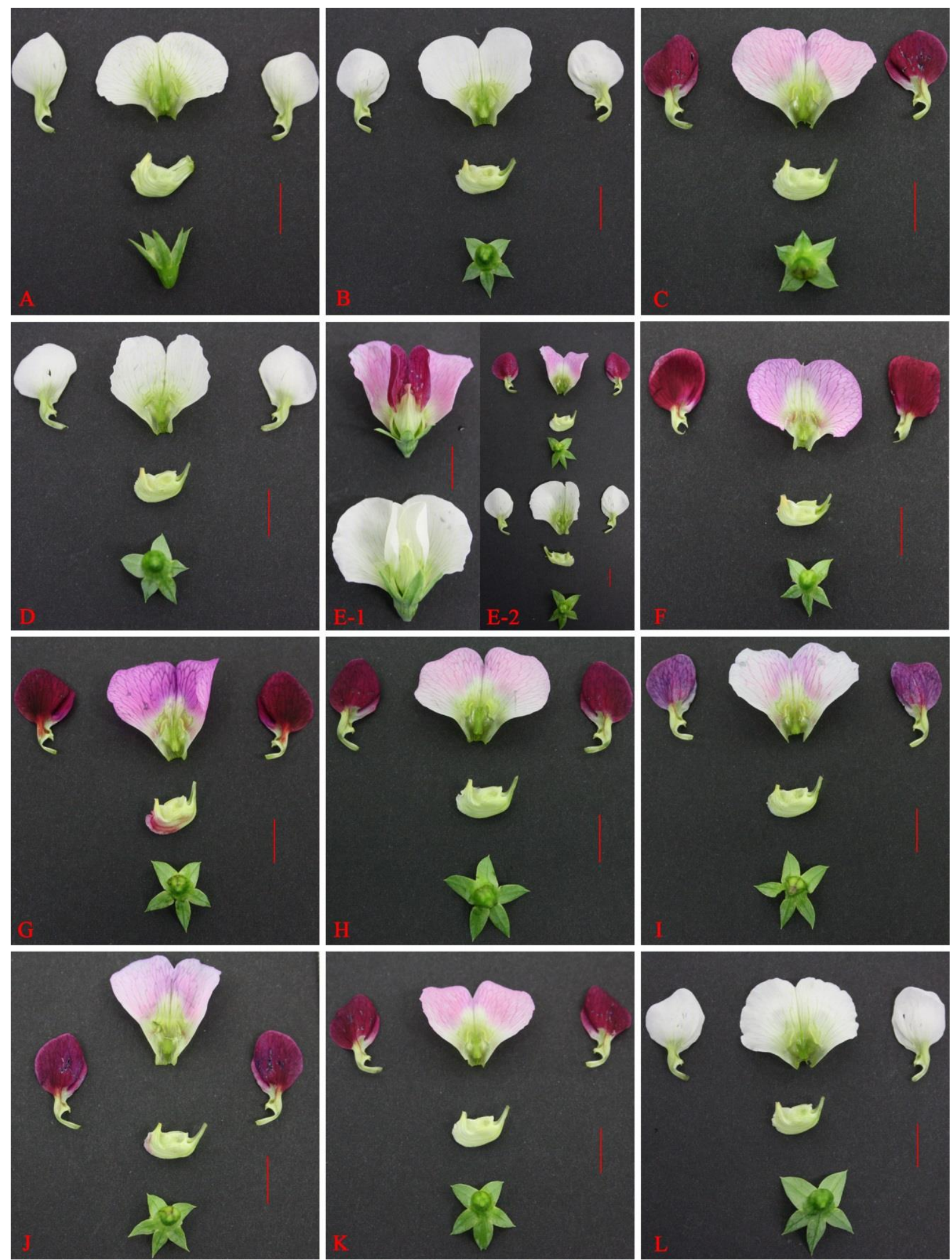

Figure 1. Images of flower parts of forage pea genotypes.

A-Crackerjack, B- Ürünlü, C-Özkaynak-1, D- Ulubatl1, E: flowers (E-1) and flowers parts (E-2) of Population-1, F-Rose, G-Töre, H-Özkaynak-2, I-Taşkent, J-Population-2, K-Özkaynak-3 and L-Gölyazı. Scale bars indicate $10 \mathrm{~mm}$.

As a result of the correlation analysis to reveal the association between yield components and flower, pod, and seed traits, a positive and significant relationship was found between fresh hay yield and standard petal length and width, keel petal length, flower length (Table 3). In addition, a significant and negative correlation was determined between fresh hay yield and seed length. It was recorded that there was a negative and significant relationship between the plant height and the number of seeds in a pod. On the other hand, there was a positive and highly significant relationship between calyx and seed traits. 
Table 2. Mean values of some generative parts of forage pea genotypes

\begin{tabular}{|c|c|c|c|c|c|c|c|}
\hline & \multicolumn{2}{|c|}{ Standard petal } & \multirow[b]{2}{*}{$\begin{array}{l}\text { Keel petal } \\
\text { length }\end{array}$} & \multicolumn{2}{|c|}{ Wing petal } & \multicolumn{2}{|c|}{ Calyx } \\
\hline $\begin{array}{l}\text { Forage Pea } \\
\text { Genotypes }\end{array}$ & length & width & & length & width & $\begin{array}{l}\text { Tube } \\
\text { length }\end{array}$ & $\begin{array}{r}\text { Teeth } \\
\text { length }\end{array}$ \\
\hline Crackerjack & $18.92 \pm 0.33 *$ & $25.87 \pm 0.36$ & $12.10 \pm 0.18$ & $18.14 \pm 0.21$ & $12.66 \pm 0.19$ & $14.85 \pm 0.34$ & $9.47 \pm 0.17$ \\
\hline Ürünlü & $21.94 \pm 0.29$ & $28.55 \pm 0.37$ & $13.14 \pm 0.16$ & $19.42 \pm 0.21$ & $13.27 \pm 0.22$ & $15.10 \pm 0.19$ & $8.57 \pm 0.19$ \\
\hline Özkaynak-1 & $23.23 \pm 0.36$ & $30.10 \pm 0.27$ & $12.74 \pm 0.07$ & $20.34 \pm 0.24$ & $13.18 \pm 0.18$ & $14.07 \pm 0.20$ & $7.81 \pm 0.18$ \\
\hline Ulubatlı & $21.90 \pm 0.30$ & $28.93 \pm 0.51$ & $12.92 \pm 0.18$ & $20.21 \pm 0.33$ & $13.35 \pm 0.22$ & $15.47 \pm 0.17$ & $9.28 \pm 0.12$ \\
\hline Population-1 & $22.76 \pm 0.50$ & $31.90 \pm 0.51$ & $13.61 \pm 0.13$ & $20.32 \pm 0.48$ & $13.26 \pm 0.22$ & $16.63 \pm 0.19$ & $10.26 \pm 0.18$ \\
\hline Rose & $21.38 \pm 0.20$ & $30.06 \pm 0.27$ & $12.14 \pm 0.15$ & $21.29 \pm 0.30$ & $14.21 \pm 0.19$ & $16.12 \pm 0.20$ & $10.30 \pm 0.14$ \\
\hline Töre & $21.75 \pm 0.28$ & $31.26 \pm 0.48$ & $12.89 \pm 0.20$ & $20.25 \pm 0.31$ & $13.52 \pm 0.22$ & $14.10 \pm 0.18$ & $8.05 \pm 0.16$ \\
\hline Özkaynak-2 & $21.91 \pm 0.19$ & $31.49 \pm 0.32$ & $12.91 \pm 0.21$ & $19.75 \pm 0.16$ & $13.49 \pm 0.16$ & $14.05 \pm 0.30$ & $7.75 \pm 0.23$ \\
\hline Taşkent & $21.84 \pm 0.16$ & $30.50 \pm 1.08$ & $12.84 \pm 0.17$ & $20.27 \pm 0.26$ & $12.72 \pm 0.26$ & $13.85 \pm 0.22$ & $7.63 \pm 0.12$ \\
\hline Population-2 & $22.44 \pm 0.35$ & $31.27 \pm 0.41$ & $12.68 \pm 0.22$ & $20.98 \pm 0.17$ & $13.22 \pm 0.23$ & $14.68 \pm 0.21$ & $7.91 \pm 0.10$ \\
\hline Özkaynak-3 & $22.35 \pm 0.27$ & $31.94 \pm 0.50$ & $13.00 \pm 0.13$ & $20.71 \pm 0.23$ & $13.48 \pm 0.19$ & $14.27 \pm 0.16$ & $7.89 \pm 0.14$ \\
\hline Gölyazı & $21.82 \pm 0.31$ & $30.41 \pm 0.43$ & $11.97 \pm 0.13$ & $20.44 \pm 0.26$ & $13.83 \pm 0.18$ & $15.11 \pm 0.24$ & $8.73 \pm 0.21$ \\
\hline $\mathrm{LSD}_{0.05}$ & 0.99 & 1.61 & 0.53 & 0.85 & 0.66 & 0.72 & 0.57 \\
\hline \multirow[b]{2}{*}{$\begin{array}{l}\text { Forage Pea } \\
\text { Genotypes }\end{array}$} & \multirow{2}{*}{$\begin{array}{l}\text { Flower } \\
\text { length }\end{array}$} & \multicolumn{2}{|c|}{ Pod } & \multicolumn{2}{|c|}{ Seed } & \multirow{2}{*}{\multicolumn{2}{|c|}{ Seed number in a pod }} \\
\hline & & length & width & length & width & & \\
\hline Crackerjack & $20.88 \pm 0.35$ & $49.57 \pm 1.84$ & $9.49 \pm 0.19$ & $6.47 \pm 0.08$ & $5.92 \pm 0.15$ & \multicolumn{2}{|c|}{$4 \pm 0.10$} \\
\hline Ürünlü & $23.55 \pm 0.28$ & $40.75 \pm 1.88$ & $8.73 \pm 0.35$ & $5.90 \pm 0.11$ & $5.27 \pm 0.31$ & \multicolumn{2}{|c|}{$4 \pm 0.16$} \\
\hline Özkaynak-1 & $25.33 \pm 0.29$ & $42.34 \pm 1.30$ & $8.10 \pm 0.26$ & $5.50 \pm 0.12$ & $4.59 \pm 0.30$ & \multicolumn{2}{|c|}{$5 \pm 0.11$} \\
\hline Ulubatlı & $24.29 \pm 0.29$ & $47.42 \pm 1.65$ & $9.27 \pm 0.39$ & $6.06 \pm 0.08$ & $5.56 \pm 0.37$ & \multicolumn{2}{|c|}{$5 \pm 0.09$} \\
\hline Population-1 & $25.00 \pm 0.32$ & $44.62 \pm 0.94$ & $10.14 \pm 0.29$ & $6.15 \pm 0.11$ & $5.56 \pm 0.20$ & \multicolumn{2}{|c|}{$3 \pm 0.21$} \\
\hline Rose & $23.62 \pm 0.28$ & $57.12 \pm 1.18$ & $10.48 \pm 0.10$ & $6.99 \pm 0.16$ & $6.18 \pm 0.16$ & \multicolumn{2}{|c|}{$6 \pm 0.12$} \\
\hline Töre & $23.60 \pm 0.41$ & $46.91 \pm 1.52$ & $8.68 \pm 0.22$ & $5.39 \pm 0.18$ & $4.52 \pm 0.37$ & \multicolumn{2}{|c|}{$5 \pm 0.10$} \\
\hline Özkaynak-2 & $23.61 \pm 0.19$ & $46.72 \pm 0.70$ & $8.89 \pm 0.23$ & $5.47 \pm 0.15$ & $4.65 \pm 0.18$ & \multicolumn{2}{|c|}{$6 \pm 0.09$} \\
\hline Taşkent & $24.75 \pm 0.28$ & $41.79 \pm 0.83$ & $8.26 \pm 0.23$ & $5.46 \pm 0.18$ & $5.09 \pm 0.31$ & \multicolumn{2}{|c|}{$4 \pm 0.15$} \\
\hline Population-2 & $25.05 \pm 0.24$ & $42.19 \pm 1.18$ & $8.82 \pm 0.20$ & $5.48 \pm 0.16$ & $4.94 \pm 0.31$ & \multicolumn{2}{|c|}{$5 \pm 0.12$} \\
\hline Özkaynak-3 & $24.52 \pm 0.29$ & $42.00 \pm 0.92$ & $8.59 \pm 0.17$ & $5.30 \pm 0.11$ & $4.61 \pm 0.21$ & \multicolumn{2}{|c|}{$5 \pm 0.14$} \\
\hline Gölyazı & $24.33 \pm 0.35$ & $54.66 \pm 1.79$ & $10.16 \pm 0.23$ & $6.44 \pm 0.11$ & $5.79 \pm 0.34$ & \multicolumn{2}{|c|}{$6 \pm 0.12$} \\
\hline $\mathrm{LSD}_{0.05}$ & 0.95 & 3.78 & 0.71 & 0.36 & 0.37 & \multicolumn{2}{|c|}{0.77} \\
\hline
\end{tabular}

*All data indicate mean \pm standard error and in millimetre except seed number in a pod.

Table 3. Correlation coefficient between agronomic and generative characteristics of forage pea genotypes.

\begin{tabular}{|c|c|c|c|c|c|c|c|c|}
\hline Characters & 1. & 2. & 3. & 4. & 5. & 6. & 7. & \\
\hline 1. Fresh hay yield & 1 & & & & & & & \\
\hline 2. Plant height & 0.350 & 1 & & & & & & \\
\hline 3. Standard petal length & $0.772 * *$ & 0.375 & 1 & & & & & \\
\hline 4. Standard petal width & $0.749 * *$ & 0.283 & $0.768 * *$ & 1 & & & & \\
\hline 5. Keel petal length & $0.602 *$ & 0.568 & 0.570 & 0.454 & 1 & & & \\
\hline 6. Wing petal length & 0.489 & 0.024 & $0.687^{*}$ & $0.744 * *$ & 0.071 & 1 & & \\
\hline 7. Wing petal width & 0.026 & -0.171 & 0.259 & 0.399 & -0.240 & $0.629 *$ & 1 & \\
\hline 8. Calyx tube length & -0.163 & 0.511 & -0.036 & -0.092 & 0.068 & 0.152 & 0.369 & \\
\hline 9.Calyx teeth lenght & -0.421 & 0.370 & -0.324 & -0.314 & -0.117 & -0.045 & 0.289 & \\
\hline 10. Flower lenght & $0.793 * *$ & 0.350 & $0.948 * *$ & 0.752 & 0.447 & $0.768 * *$ & 0.190 & \\
\hline 11. Pod width & -0.316 & 0.250 & -0.296 & -0.104 & -0.348 & 0.112 & 0.533 & \\
\hline 12. Pod length & -0.459 & -0.237 & -0.442 & -0.206 & -0.721 & 0.102 & $0.625 *$ & \\
\hline 13. Seed number in a pod & -0.083 & $-0.660 *$ & 0.055 & 0.202 & -0.574 & 0.403 & $0.701 *$ & \\
\hline 14. Seed width & -0.557 & 0.079 & -0.524 & -0.527 & -0.483 & -0.128 & 0.197 & \\
\hline 15. Seed length & $-0.621 *$ & 0.053 & -0.484 & -0.481 & -0.538 & -0.079 & 0.379 & \\
\hline Characters & 8. & 9. & 10. & 11. & 12. & 13. & 14. & 15. \\
\hline 8. Calyx tube length & 1 & & & & & & & \\
\hline 9.Calyx teeth lenght & $0.932 * *$ & 1 & & & & & & \\
\hline 10. Flower lenght & -0.018 & -0.300 & 1 & & & & & \\
\hline 11. Pod width & $0.842 * *$ & $0.866 * *$ & -0.240 & 1 & & & & \\
\hline 12. Pod length & 0.438 & $0.588^{*}$ & -0.382 & $0.805 * *$ & 1 & & & \\
\hline 13. Seed number in a pod & -0.213 & -0.213 & 0.039 & 0.129 & 0.550 & 1 & & \\
\hline 14. Seed width & $0.755 * *$ & $0.847 * *$ & -0.401 & $0.838 * *$ & $0.695^{*}$ & -0.056 & 1 & \\
\hline 15. Seed length & $0.759 * *$ & $0.871 * *$ & -0.421 & $0.881 * *$ & $0.808 * *$ & 0.096 & $0.959 * *$ & 1 \\
\hline
\end{tabular}




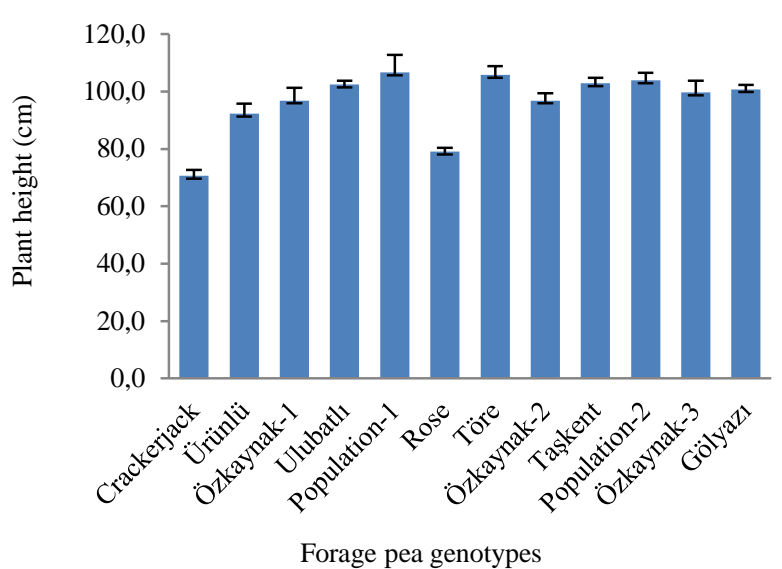

Figure 2. Mean values of plant height of forage pea genotypes. Bars indicate standard error

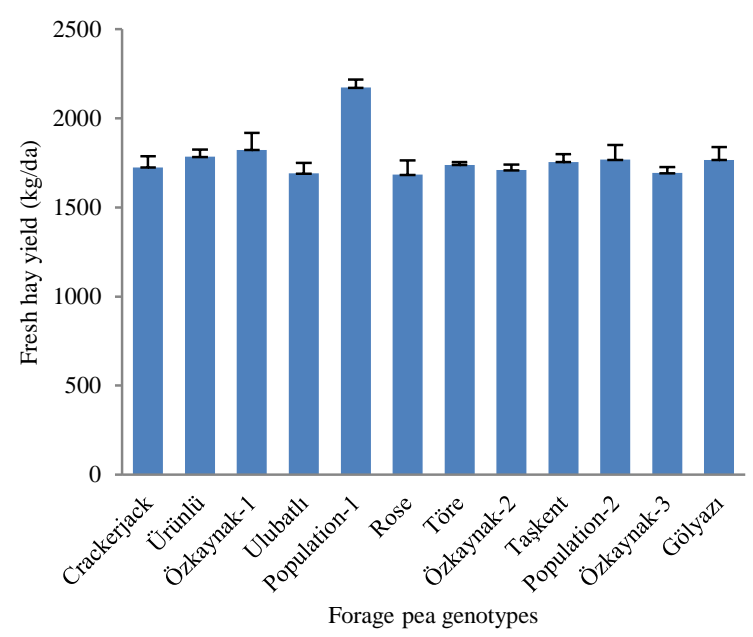

Figure 3. Mean values of fresh hay yield of forage pea genotypes. Bars indicate standard error

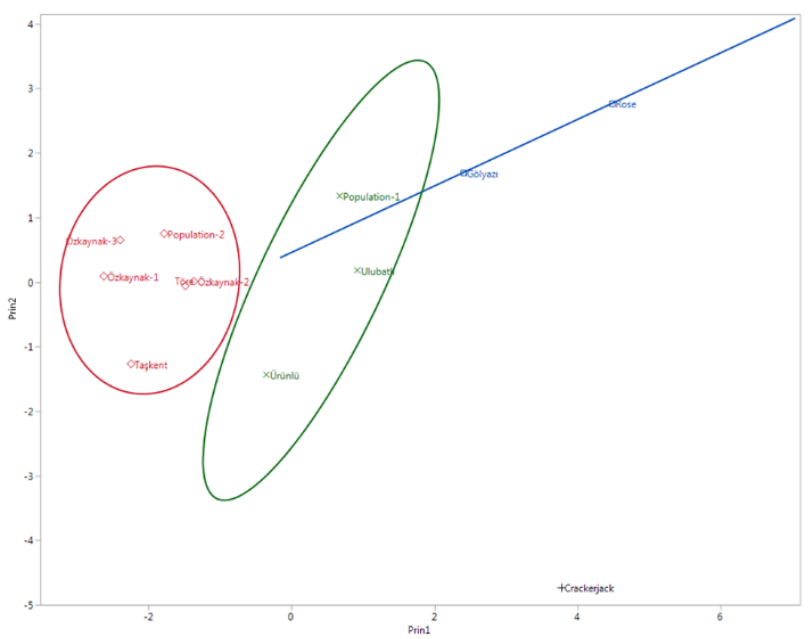

Figure 4. Classification of 12 forage pea genotypes according to flower, pod and seed characters using a combination of Principal Component and Cluster Analysis. Prin indicates Principal Component Analysis.

Both morphological and agronomic characterization is the first step in the classification of plant genetic resources. Our results demonstrated that there was an enormous variation in the available forage pea genotypes. In Turkey, forage pea genotypes collected from North East Anatolia and Eastern Black Sea regions indicated immense variation regarding agro-morphological characteristics similar to these findings (Tan et al., 2012; Tan et al., 2013; Demirkol and Y1lmaz, 2019). Plant heights and dry matter yields of forage pea genotypes ranged from 68.8 to $102 \mathrm{~cm}$ and 486 to $677 \mathrm{~kg} / \mathrm{da}$, respectively according to Tan et al. (2013).

There is limited number of studies on the detailed flower characteristics of peas related to agronomic traits and these are usually taxonomic studies. Davis (1970) reported that the flower of $P$. sativum was $16-30 \mathrm{~cm}$ with lilac standard and darker reddish-purple wings, or flowers white and calyx was $8-15(-20) \mathrm{mm}$. In the 246 genotypes of Pisum sativum L., collected from various parts of the world, it was determined that the flower color was $61 \%$ white, 36\% pink and 2\% mixed (Nisar et al., 2008).

There are a lot of studies on pod characteristics rather than flower traits of pea genotypes. Contrary to these findings, a wide genetic diversity of pea was investigated by Nisar et al. (2011), dry pod length and width ranged from 31.74 to $91.38 \mathrm{~mm}$ and $1.01-19.2 \mathrm{~mm}$, respectively in 286 pea genotypes. Similar to the previous study, Umar et al. (2014) recorded that pod length and width of pea genotypes were varied from 17.3-85.5 $\mathrm{mm}$ and 2-9 $\mathrm{mm}$, respectively.

There are limited studies of seed characteristics, and these are generally related to agronomic characters. Davis (1970) stated that the number of seeds in a pod was between 3 and 10 and the diameter of the seeds was at least $5 \mathrm{~mm}$ in $P$. sativum. Tan et al. (2012) determined that the number of seeds in a pod ranged from 3.5-5.6 in local forage pea genotypes of Turkey similar to these findings.

As a result of clustering based on flower, fruit and seed characteristics, there was no grouping related to agronomic characteristics of the genotypes. Nevertheless, the forage pea genotypes which has standard petal with violet, light, and dark violet colours, were mostly in the first group. Sincik et al (2004) demonstrated that pea genotypes with colourful flowers were more cold resistant than white ones.

The relationships between morphologic and agronomic traits differed from other findings. Gatti et al. (2011) demonstrated that pea genotypes had a positive correlation between plant height and both seed diameter and 100 seed weight. Ofga and Petros (2017) reported that there was a positive correlation between biomass and plant height, while a negative relationship between biomass and pod length. Also, the positive correlations were determined between plant height and both herbage and hay yields in forage pea genotypes (Çacan et al. 2019).

In conclusion, forage pea genotypes revealed significant differences in terms of both agronomic and flower, pod, and seed characteristics. Population-1, introduced from Russia, gave the highest plant height and fresh hay yield. In the cluster analysis based on the investigated morphological traits, genotypes were mostly clustered according to flower colours rather than agronomic characters. There was a highly significant positive correlation between fresh hay yield and both standard petal width and length and flower length. However, fresh hay yield decreased as seed length increased. It was concluded that Population -1 is a hopeful genotype and some flower and seed characters can be used for pre-selection of forage pea genotypes. 


\section{References}

Ali Z, Qureshi AS, Ali W, Gulzar H, Nisar M, Ghafoor A. 2007. Evaluation of genetic diversity present in pea (Pisum sativum L.) germplasm based on morphological traits, resistance to powdery mildew and molecular characteristics. Pakistan Journal of Botany, 39: 2739-2747.

Cacan E, Kokten K, Bakoglu A, Kaplan M, Bozkurt A. 2019. Evaluation of some forage pea (Pisum arvense L.) lines and cultivars in terms of herbage yield and quality. Harran Tarım ve Gida Bilimleri Dergisi, 23(3): 254-262. doi: 10.29050/harranziraat.446423.

Hedge IC. 1970. Pisum L. In: Davis, PH (ed.) Flora of Turkey and the East Aegean Islands, Vol. 3, pp. 370. Edinburgh: Edinburgh University Press.

Demirkol G, Y1lmaz N. 2019. Forage pea (Pisum sativum var. arvense L.) landraces reveal morphological and genetic diversities. Turkish Journal of Botany, 43(3): 331-342. doi: 10.3906/bot-1812-12.

Fraser MD, Fychan R, Jones R. 2001. The effects of harvest date and inoculation on the yield, fermentation characteristics and feeding value of forage pea and field bean silages. Grass and Forage Science, 56: 218-230. doi: 10.1046/j.13652494.2001.00268.x.

Gatti I, Espósiton M, Almirón P, Cravero V, Cointry E. 2011. Diversity of pea (Pisum sativum) accessions based on morphological data for sustainable field pea breeding in Argentina. Genetics and Molecular Research 10: 3403-3410. doi: 10.4238/2011.October.31.8.

Kosterin OE, Zaytseva OO, Bogdanova VS, Ambrose M. 2010. New data on three molecular markers from different cellular genomes in Mediterranean accessions reveal new insights into phylogeography of Pisum sativum L. subsp elatius (Bieb.) Schmalh. Genetic Resources and Crop Evolution, 57: 733-739.

Maxted N, Ambrose N. 2000. Peas (Pisum L.) Chapter 10. In: Maxted N and Bennett SJ (eds) Plant Genetic Resources of Legumes in the Mediterranean. Dordrecht: Kluwer Academic Publishers, pp. 181-190. ISBN: 0-7923-6707-3.

Maxted N, Hargreaves S, Kell SP, Amri A, Street K, Shehadeh A, Piggin J, Konopka J. 2010. Temperate forage and pulse legume genetic gap analysis. Paper given at XIII OPTIMA Meeting in Antalya, Turkey, 22-26 March 2010.

Muehlbauer FJ, Tullu A. 1997. Pisum sativum L.. In: NewCrop Factsheet, Purdue University, Center for New Crops \& Plant Products. Available from: https:// hort.purdue.edu/newcrop/ CropFactSheets/pea.html.
Nisar M, Ghafoor A, Ahmad H, Khan M, Qureshi A, Ali H. 2008. Evaluation of genetic diversity of pea germplasm through phenotypic trait analysis. Pakistan Journal of Botany. 40: 2081-2086.

Nisar M, Ghafoor A, Khan M. 2011. Phenotypic variation in the agronomic and morphological traits of Pisum sativum L. germplasm obtained from different parts of the world. Russian Journal of Genetics, 47: 19-25. doi: 10.1134/S102279541012104X.

Oelke EA, Oplinger ES, Hanson CV, Davis DW, Putnam DH, Fuller EI, Rosen CJ. 1991. Dry field pea. Alternative Field Crop Manual, University of Wisconsin-Exension, Cooperative Extension.

Ofga B, Petros Y. 2017. Genetic Variability and association among agronomic characters in selected field pea (Pisum sativum L.) genotypes at Bale Zone, Sinana Research Center, Oromia Region, Ethiopia. International Journal of Genetics and Genomics, 5(6): 63-75. doi: 10.11648/j.ijgg. 20170506.11.

Sincik M, Bilgili U, Uzun A, Acikgoz E. 2005. Effect of low temperatures on the germination of different field pea genotypes. Seed Science and Technology, 32(2): 331-339. DOI: 10.15258/sst.2004.32.2.06.

Smith JS, Smith OS. 1989. The description and assessment of distance between inbreed lines of maize, II: The utility of morphological, biochemical and genetic descriptors and a scheme for testing of distinctiveness between inbreed lines. Maydica, 34: 151-161.

Tan M, Koç A, Dumlugül Z. 2012. Morphological characteristics and seed yield of East Anatolian local forage pea (Pisum sativum ssp. arvense L.) ecotypes. Turkish Journal of Field Crops, 2012, 17(1): 24-30.

Tan M, Koç A, Dumlugül Z, Elkoca E, Gül İ. 2013. Determination of dry matter yield and yield components of local forage pea (Pisum sativum ssp. arvense L.) ecotypes. Journal of Agricultural Sciences, 19: 289-296.

Tiwari G, Lavanya GR. 2012. Genetic variability, character association and component analysis in F4 generation of field pea (Pisum sativum var. arvense L.). Karnataka Journal of Agricultural Science, 25(2): 173-175.

Umar HMİ, Ur-Rehman S, Bilal M, Naqvi, SAH, Manzoor SA, Ghafoor A, Khalid M, Iqbal MT, Qayyum A, Ahmad F, Irshad MA. 2014. Evaluation of genetic diversity in pea (Pisum sativum) based on morpho-agronomic characteristics for yield and yield associated traits. Journal of Biodiversity and Environmental Sciences, 4(5): 321-328. 